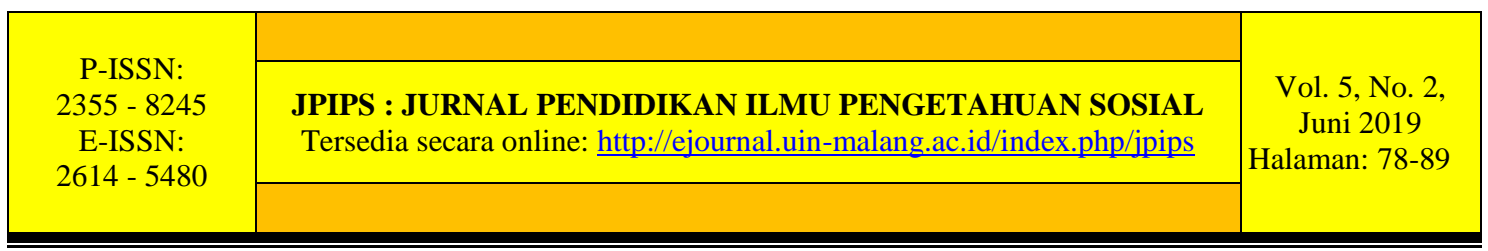

\title{
PENGARUH GROUP INVESTIGATION DAN GAYA BELAJAR TERHADAP HASIL BELAJAR GEOGRAFI MAHASISWA PENDIDIKAN IPS
}

\author{
Saiful Amin \\ Universitas Islam Negeri Maulana Malik Ibrahim Malang \\ amin.geo87@pips.uin-malang.ac.id
}

\begin{abstract}
Abstrak: Penelitian ini bertujuan 1) mengetahui pengaruh model Group Investigation terhadap hasil belajar geografi; 2) mengetahui pengaruh gaya belajar terhadap hasil belajar geografi; dan 3) mengetahui interaksi antara model Group Investigation dan gaya belajar terhadap hasil belajar geografi. Rancangan penelitian menggunakan eksperimen semu dengan desain faktorial sederhana $2 \times 3$, yang mengacu pada desain control group pretest-posttest. Analisis data hasil belajar menggunakan teknik ANOVA (Analysis of Variance) Dua Jalur pada taraf signifikansi 5\%. Hasil penelitian menunjukkan bahwa 1) model Group Investigation berpengaruh terhadap hasil belajar geografi mahasiswa PIPS UIN Maulana Malik Ibrahim Malang; 2) gaya belajar berpengaruh terhadap hasil belajar geografi mahasiswa PIPS UIN Maulana Malik Ibrahim Malang; 3) model GI dan gaya belajar tidak berinteraksi secara signifikan berpengaruh terhadap hasil belajar geografi mahasiswa PIPS UIN Maulana Malik Ibrahim Malang.
\end{abstract}

Kata Kunci: Group Investigation; gaya belajar; hasil belajar geografi

Abstract: This study aims to 1) determine the effect of the Group Investigation model on geography learning outcomes; 2) knowing the effect of learning styles on geography learning outcomes; and 3) knowing the interaction between the Group Investigation model and learning styles towards geography learning outcomes. The study design used quasi-experimental with a simple $2 \times 3$ factorial design, which refers to the pretestposttest control group design. Analysis of learning outcome data using the Two Path Analysis of Variance ANOVA technique at a significance level of 5\%. The results of the study show that 1) the Group Investigation model influences the geography learning outcomes of PIPS students at Maulana Malik Ibrahim State Islamic University of Malang; 2) learning styles influence the geography learning outcomes of PIPS students at Maulana Malik Ibrahim State Islamic University of Malang; 3) GI models and learning styles do not interact significantly influence the geography learning outcomes of PIPS students at Maulana Malik Ibrahim State Islamic University of Malang.

Keywords: Group Investigation; learning style; geography learning outcomes

\section{PENDAHULUAN}

Model pembelajaran Group Investigation (GI) pertama kali dikenalkan oleh Herbert Thelen pada tahun 1960, kemudian dikembangkan dan disempurnakan Shlomo Sharan, 
Yael Sharan, dkk. di Universitas Tel Aviv, Israel pada tahun 1984 (Kagan \& Kagan, 2009). Model GI merupakan investigasi kelompok yang berusaha mencampurkan bentuk strategi pengajaran dengan dinamika proses demokrasi dan akademis berupa penelitian. Pemikiran dasar pada model GI adalah bentuk pengajaran pada kelompok kecil (Sharan \& Sharan, 1989).

Model GI didesain agar siswa belajar dan bekerja sama pada kelompok kecil berjumlah 4-5 orang. Siswa bekerja dalam kelompok kecil untuk menyelidiki permasalahan pada materi pembelajaran (Kagan \& Kagan, 2009). Model GI melibatkan siswa secara langsung dan aktif dalam pembelajaran mulai dari perencanaan hingga mempelajari suatu permasalahan melalui investigasi secara kelompok.

Pembelajaran model GI berpusat pada siswa dalam usaha mencapai peningkatan hasil belajar. Siswa dilatih mengajukan pertanyaan, ide, menyanggah, atau mempertahankan gagasannya dalam pembelajaran diskusi. Model pembelajaran GI memiliki ciri-ciri (1) siswa aktif dalam pembelajaran, siswa belajar materi dengan bekerja dan berpikir, (2) informasi baru dikaitkan dengan informasi sebelumnya agar menyatu dengan skema yang dibangun siswa, dan (3) orientasi pembelajaran dengan investigasi dan penemuan untuk pemecahan masalah (Sumaatmadja, 1996).

Salah satu tahapan penting adalah pelaksanaan investigasi. Investigasi merupakan kegiatan siswa menyelidiki permasalahan pada materi pelajaran yang dipilih. Salah satu rangkaian investigasi adalah siswa aktif mencari materi pelajaran melalui buku pelajaran, media massa, dan internet. Siswa melakukan investigasi terhadap suatu topik secara terstruktur dan analitik, sehingga terjadi perkembangan keterampilan penemuan untuk membantu mencapai tujuan pembelajaran.

Investigasi memberikan arahan kepada siswa untuk mengkaji permasalahan materi pembelajaran secara mendalam dan memberikan pengalaman, mengumpulkan, menyusun informasi, dan belajar secara mandiri. Siswa yang diberdayakan aktif menemukan pengetahuan secara mandiri akan berimbas pada pemahaman yang mendalam terhadap materi pelajaran dan berpengaruh terhadap hasil belajar (Ketut, 2010). Keunggulan dari model pembelajaran GI menurut Sumarmi, yaitu (1) siswa memiliki keterampilan inkuiri, (2) siswa lebih intensif dalam meneliti untuk mencari dan menemukan solusi pemecahan masalah, (3) siswa menjadi terampil dalam berdiskusi serta bekerja kelompok, (4) siswa menjadi lebih aktif dalam pembelajaran, baik secara mandiri maupun diskusi kelompok (Sumarmi, 2012).

Tahapan pembelajaran model GI dapat mengaktifkan siswa dalam pembelajaran (Arnyana, 2004). Model pembelajaran GI memfasilitasi siswa untuk belajar secara aktif. Siswa tidak hanya duduk diam dan mencatat selama belajar, tetapi aktif dalam mengikuti setiap tahapan pembelajaran yang ada.

Model GI mendorong siswa aktif dalam menguasai materi dan mencapai hasil belajar melalui pembelajaran berkelompok. Kelompok siswa pada model GI memiliki anggota yang heterogen dari segi kemampuan akademik, ras, dan jenis kelamin. Apabila anggota kelompok tidak mengerjakan tugas dengan baik maka tujuan kelompok secara keseluruhan tidak akan tercapai. Pencapaian tujuan kelompok ditentukan oleh kesungguhan anggota kelompok (Slavin, 2005).

Berdasarkan berbagai pendapat yang dikemukakan, kehebatan model GI terletak pada: (1) adanya penemuan pengetahuan baru melalui proses belajar mandiri; (2) siswa memiliki kemampuan berkomunikasi baik; (3) adanya motivasi yang mendorong siswa untuk aktif dalam pembelajaran; (4) kerjasama kelompok membangkitkan semangat siswa dalam pembelajaran. Hal tersebut sejalan dengan Hasan, dkk. bahwa tujuan yang 
ingin dicapai pada pembelajaran melalui model GI, yaitu (1) membangun sikap belajar kelompok dan kemampuan bersosialisasi, (2) membangun kemampuan bekerjasama, (3) melatih kecakapan berkomunikasi dalam kelompok kecil maupun antar kelompok, (4) meningkatkan prestasi akademiknya siswa baik secara individu maupun kelompok (Hasan, Rakhman, \& Ardiana, 2017).

Pendapat di atas dapat menunjukkan bahwa tujuan penggunaan model pembelajaran GI yaitu: (1) untuk meningkatkan hasil belajar siswa baik secara individu maupun berkelompok, (2) memberikan beberapa orientasi lain bagi siswa dalam meningkatkan hasil belajarnya maupun sebagai makhluk sosial yaitu dengan adanya sikap kerjasama, bersosialisasi aktif dan pengembangan diri, dan (3) peningkatan motivasi siswa dalam kegiatan belajar pada proses yang menyenangkan dan keterlibatan aktif. Hal inilah yang menjadikan ketertarikan peneliti untuk mengujicobakan model pembelajaran GI untuk mengetahui pengaruhnya terhadap hasil belajar mahasiswa Pendidikan IPS UIN Maulana Malik Ibrahim Malang.

Secara empirik, pengaruh model GI terhadap hasil belajar ditunjukkan dengan hasil penelitian Fajariningtyas pada hasil tes penguasaan materi pada mahasiswa Universitas Wiraraja Sumenep Madura lebih tinggi dengan penggunaan model GI (Fajarianingtyas, 2012). Temuan tersebut sejalan dengan hasil penelitian Raharjo bahwa model GI berpengaruh secara signifikan terhadap hasil belajar (Raharjo, 2010). Selanjutnya, hasil penelitian Dewi, dkk. menunjukkan bahwa terdapat pengaruh yang signifikan model pembelajaran GI terhadap hasil belajar pada kelas ekperimen dibandingkan dengan kelas kontrol yang menggunakan ceramah dan diskusi pada pelajaran kimia (Dewi, Iswari, \& Susanti, 2012). Berdasarkan hasil penelitian tersebut menunjukkan bahwa model GI memberikan pengaruh signifikan terhadap hasil belajar.

Selain model pembelajaran, keberhasilan pembelajaran dipengaruhi juga oleh gaya belajar siswa. Gaya belajar merupakan cara seseorang dalam menyerap informasi dan mengolahnya agar informasi tersebut dapat diterima (De Porter \& Hernacki, 2015). De Porter menjelaskan bahwa pada awal pembelajaran, langkah pertama guru ialah mengenali modalitas (gaya belajar) siswa, yaitu visual, auditotrial, atau kinestetik (V-A$\mathrm{K})$. Walaupun terkadang dalam pembelajaran, beberapa siswa menggunakan kombinasi dari ketiga gaya belajar. Kegiatan pembelajaran yang disesuaikan dengan gaya belajar siswa akan dapat terlaksana dengan maksimal (De Porter \& Hernacki, 2015).

Secara empirik, pengaruh model GI dan gaya belajar terhadap hasil belajar didukung oleh hasil penelitian Richardo bahwa (1) hasil belajar siswa dengan menggunakan model pembelajaran kooperatif tipe investigasi kelompok lebih baik dibandingkan menggunakan model pembelajaran langsung. (2) Prestasi belajar matematika siswa dengan gaya belajar visual lebih baik daripada siswa dengan gaya belajar kinestetik dan auditorial. (3) Prestasi belajar matematika siswa dengan gaya belajar kinestetik lebih baik daripada siswa dengan gaya belajar auditorial. (4) tidak terdapat interaksi antara model pembelajaran dan gaya belajar terhadap prestasi belajar matematika (Richardo, 2015). Selanjutnya, hasil penelitian Windiatmoko mengenai pengaruh model GI dan gaya belajar terhadap hasil belajar, yaitu: 1) Model pembelajaran Group Investigation berpengaruh terhadap hasil belajar kognitif biologi; 2) Gaya belajar tidak berpengaruh terhadap hasil belajar kognitif biologi; 3) Interaksi antara model pembelajaran dengan gaya belajar tidak berpengaruh terhadap hasil belajar kognitif biologi siswa SMA Negeri 5 Surakarta tahun pelajaran 2011/2012 (Windiatmoko, 2012). 
Berdasarkan kajian teori dan empirik di atas, diduga bahwa hasil belajar geografi akan meningkat apabila diterapkan model GI dengan memperhatikan masing-masing gaya belajar siswa. Hasil penelitian-penelitian terdahulu dijadikan acuan dalam penelitian ini untuk mengetahui pengaruh model GI dan gaya belajar siswa terhadap hasil belajar. Penelitian ini bertujuan 1) mengetahui pengaruh model Group Investigation terhadap hasil belajar geografi mahasiswa Pendidikan IPS UIN Maulana Malik Ibrahim Malang; 2) mengetahui pengaruh gaya belajar terhadap hasil belajar geografi mahasiswa Pendidikan IPS UIN Maulana Malik Ibrahim Malang; dan 3) mengetahui interaksi antara model Group Investigation dan gaya belajar terhadap hasil belajar geografi mahasiswa Pendidikan IPS UIN Maulana Malik Ibrahim Malang.

\section{METODE}

Rancangan penelitian ini menggunakan eksperimen semu dengan desain faktorial sederhana $2 \times 3$. Bentuk rancangan tersebut dilakukan dengan mengacu pada desain control group pretest-posttest. Subyek dari penelitian ini adalah mahasiswa Jurusan Pendidikan IPS semester genap tahun ajaran 2016/2017 yang mengampu matakuliah Geografi Regional. Instrumen penilaian gaya belajar yang digunakan dalam penelitian ini adalah angket gaya belajar berupa VAK Learning Test. Instrumen penilaian hasil belajar yang digunakan dalam penelitian ini adalah tes esai yang didasarkan pada indikator pembelajaran. Pengujian instrumen dalam penelitian ini meliputi validitas dan reliabilitas soal. Pengumpulan data dalam penelitian ini digunakan untuk mendapatkan data hasil belajar mahasiswa yang didapatkan dari nilai prates dan pascates. Pengujian hipotesis pada nilai gain skor diperoleh dari hasil pengurangan antara nilai pascates dan prates. Analisis terhadap data hasil belajar menggunakan teknik ANOVA (Analysis of Variance) Dua Jalur pada taraf signifikansi 5\%.

\section{HASIL DAN PEMBAHASAN \\ Hasil}

\section{Gaya Belajar Siswa Kelas Eksperimen dan Kontrol}

Gaya belajar mahasiswa kelas C (sebagai kelas eksperimen) dan kelas D (sebagai kelas kontrol) di Jurusan Pendidikan IPS, UIN Maulana Malik Ibrahim Malang berupa visual, auditorial, dan kinestetik. Perbandingan persentase gaya belajar mahasiswa pada kedua kelas divisualisasikan pada gambar berikut.

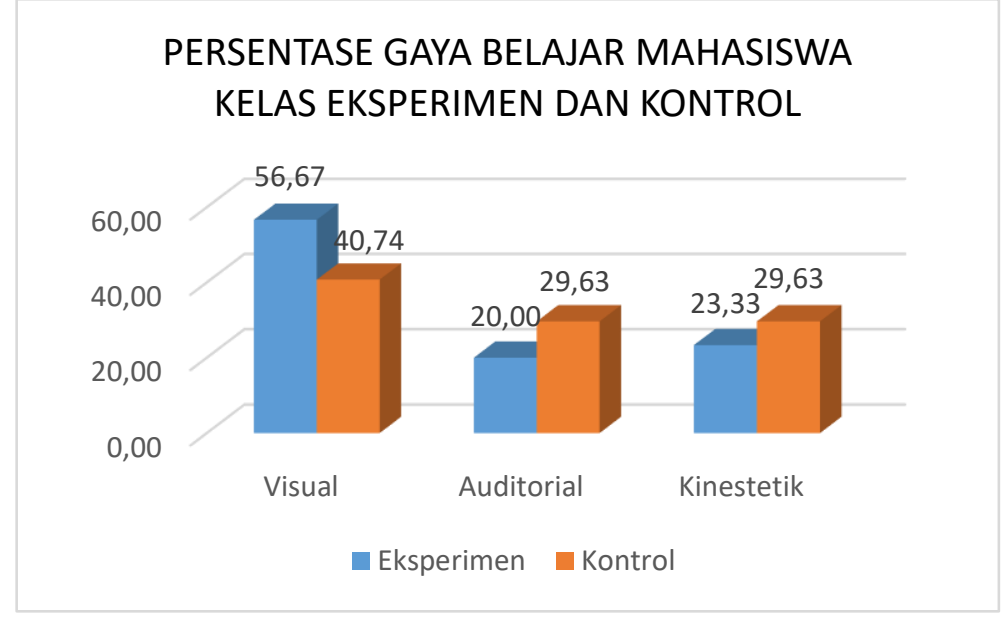

Gambar 1. Persentase Gaya Belajar Mahasiswa 
Berdasarkan gambar di atas bahwa baik kelas ekperimen maupun kelas kontrol didominasi oleh gaya belajar visual. Persentase gaya belajar visual pada kelas eksperimen lebih besar 15,93\% dari kelas kontrol. Persentase gaya belajar auditorial pada kelas kontrol lebih besar 9,63\% dari kelas eksperimen. Selanjutnya, persentase gaya belajar kinestetik pada kelas eksperimen lebih besar 6,30\% dari kelas kontrol.

\section{Hasil Belajar Mahasiswa Kelas Eksperimen Dan Kontrol}

Data hasil belajar mahasiswa terdiri dari skor rata-rata pretest, posttest, dan gain score. Rata-rata hasil belajar mahasiswa divisualisasikan pada gambar berikut.

\section{RATA-RATA HASIL BELAJAR MAHASISWA KELAS EKSPERIMEN DAN KONTROL}

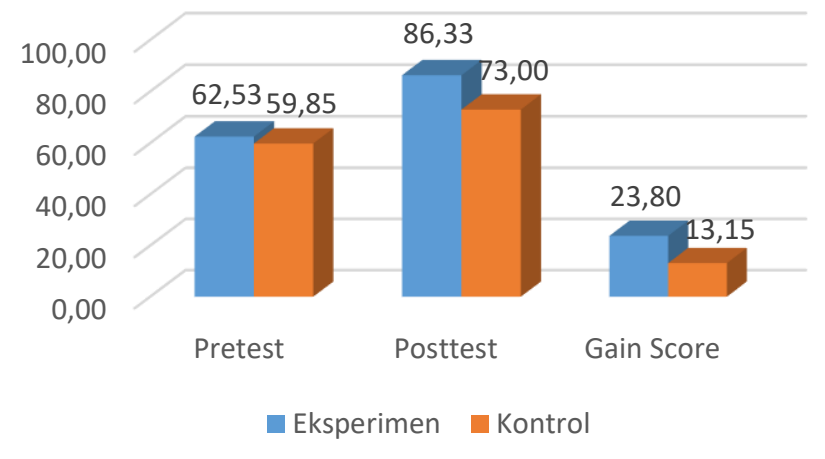

Gambar 2. Rata-Rata Hasil Belajar Siswa Kelas Eksperimen dan Kontrol

Statistik hasil belajar menunjukkan bahwa: (1) nilai rata-rata pretest kelas eksperimen lebih rendah; (2) nilai rata-rata posttest kelas eksperimen lebih tinggi; dan (3) nilai rata-rata gain skor kelas eksperimen lebih tinggi. Berdasarkan uraian data mean tersebut, dapat disimpulkan bahwa model pembelajaran Group Investigation berpengaruh terhadap hasil belajar geografi mahasiswa IPS.

\section{Hasil Belajar Ditinjau dari Gaya Belajar Mahasiswa}

Data hasil belajar ditinjau dari gaya belajar mahasiswa terdiri dari skor rata-rata gain score. Rata-rata hasil belajar ditinjau dari gaya belajar mahasiswa divisualisasikan pada gambar berikut. 


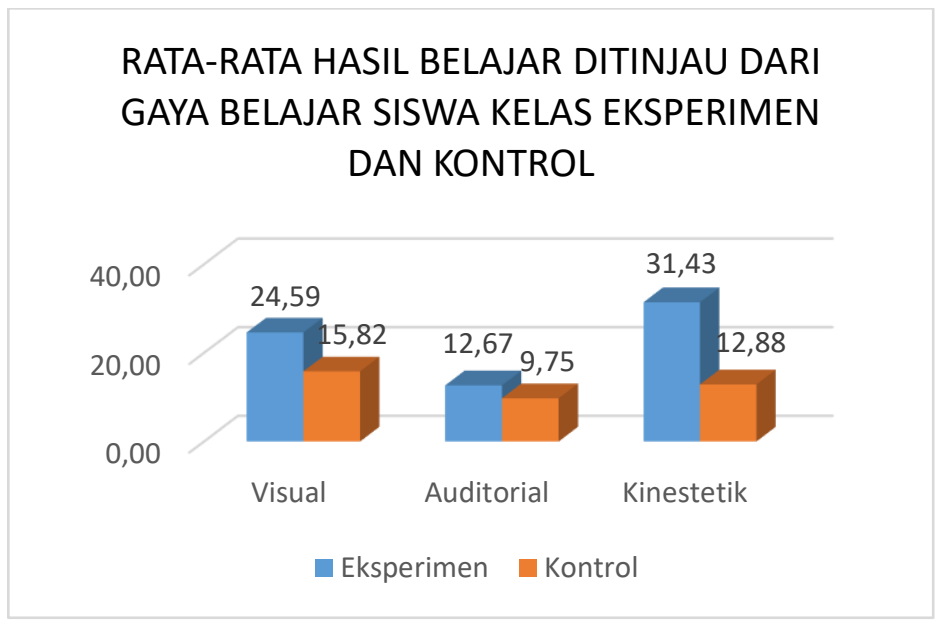

Gambar 3. Rata-Rata Hasil Belajar Ditinjau dari Gaya Belajar Mahasiswa

Berdasarkan gambar di atas dapat disimpulkan bahwa rata-rata hasil belajar mahasiswa pada kelas kontrol dengan gaya belajar visual > kinestetik > auditorial. Selanjutnya rata-rata hasil belajar mahasiswa pada kelas eksperimen dengan gaya belajar kinestetik > visual > auditorial.

Hasil belajar mahasiswa yang diujikan dengan menggunakan ANOVA Dua Jalur berupa gain score hasil belajar. Rangkuman hasil analisis dapat dilihat pada tabel berikut.

Tabel 1. Rangkuman Hasil Analisis Uji ANOVA Dua Jalur

\begin{tabular}{|c|c|c|c|c|}
\hline Variabel & Df & Mean Square & $\mathbf{F}$ & Sig. \\
\hline Model Pembelajaran & 1 & 1289,344 & 13,532 & 0,001 \\
\hline $\begin{array}{l}\text { Gaya Belajar } \\
\text { Model }\end{array}$ & 2 & 502,903 & 5,278 & 0,008 \\
\hline $\begin{array}{l}\text { Pembelajaran*Gaya } \\
\text { Belajar }\end{array}$ & 2 & 227,624 & 2,389 & 0,102 \\
\hline
\end{tabular}

Berdasarkan tabel di atas, hasil analisis uji Anova Dua Jalur menunjukkan (1) variabel bebas penggunaan model pembelajaran memiliki nilai signifikansi 0,001 terhadap hasil belajar, (2) variabel moderator gaya belajar memiliki nilai signifikansi 0,008 terhadap hasil belajar, dan (3) interaksi antara variabel model pembelajaran dan gaya belajar memiliki nilai signifikansi 0,102 terhadap hasil belajar geografi.

\section{Pembahasan}

\section{Model GI Berpengaruh terhadap Hasil Belajar Geografi Mahasiswa Pendidikan IPS}

Berdasarkan nilai rata-rata gain score dan hasil uji anova dua jalur menunjukkan bahwa pembelajaran geografi regional pada materi permasalahan perekonomian pada negara-negara berkembang di Benua Asia dengan menggunakan model Group Investigation berpengaruh terhadap hasil belajar. Hal tersebut ditunjukkan dengan nilai rata-rata gain score pada kelas eksperimen lebih besar dari kelas kontrol. Selain itu analisis uji anova dua jalur menunjukkan hasil yang signifikan.

Identifikasi alasan bahwa model GI berpengaruh terhadap hasil belajar, yaitu pertama, GI dalam pembelajaran ini menekankan pada perencanaan kelompok. Keseluruhan anggota kelompok berpikir dan mengkomunikasikan perencanaan yang terbaik dalam menyelesaikan tugas kelompok. Kegiatan pada perencanaan ini membuat siswa menjadi 
lebih aktif. Hal ini tampak ketika siswa bekerja sama dalam merancang laporan presentasi. Diskusi antar siswa dalam kelompok memberikan kebebasan dan menghilangkan rasa malu dalam mengeluarkan pendapat (Roestiyah, 2008).

Tanggung jawab individu dari masing-masing anggota kelompok dalam perencanaan menyelesaikan tugas kelompok dapat meningkatkan pemahaman terhadap materi pelajaran (Joyce, Weil, \& Calhoun, 2008). Siswa tanggung jawab dalam berbagi informasi sesama teman dalam diskusi kelompok. Masing-masing anggota mendapatkan informasi baru yang terkait dengan materi pelajaran. Kunci keberhasilan dalam kelompok ini adalah setiap anggota menyumbangkan seluruh pemikiran dan mengajari antar sesama teman terkait dengan materi pelajaran yang masing-masing telah dipahami.

Materi permasalahan perekonomian pada negara-negara berkembang di Benua Asia yang menggunakan model $G I$, siswa diberikan waktu lebih banyak untuk menyelidiki, mencacat, dan memahami materi kemudian menyampaikan dan memadukannya dalam kelompok. Adanya pemberian waktu yang lebih banyak ini memberikan kesempatan kepada siswa untuk dapat menguasai materi. Salah satu kelebihan model GI, yaitu memberikan kesempatan siswa untuk bertanggung jawab mengajarkan materi kepada sesama teman dalam kelompok dan saling berbagi ide (Kurniajanti, 2012). Secara nyata keunggulan GI yang diaplikasikan dalam pembelajaran geografi dari hasil penelitian ini ditunjukkan dengan hasil belajar yang lebih tinggi daripada pembelajaran ceramah dan diskusi kelompok.

Kedua, siswa dapat bekerja sama dalam kelompok kecil yang heterogen. Siswa bergabung dalam kelompok yang berjumlah 4-6 orang yang memiliki kemampuan tinggi dan kemampuan rendah. Kerja kelompok pada model GI mengharuskan siswa berusaha memahami materi pelajaran yang menjadi tugasnya dalam kelompok (Zingaro, 2008). Sesama anggota kelompok saling berdiskusi, menyampaikan pendapat, dan saling membantu melalui kerja kelompok dalam menyelesaikan tugas. Apabila satu teman belum memahami materi, tugas teman yang lain untuk menjelaskan materi yang belum dipahami tersebut.

Siswa yang belajar dalam kelompok akan lebih banyak mendapatkan informasi materi pelajaran dibandingkan siswa yang belajar sendiri. Dalam kelompok siswa saling berbagi informasi yang berkaitan dengan materi pelajaran. Siswa mengerjakan tugas secara berkelompok dapat meningkatkan hasil belajar karena pemahaman terhadap materi pelajaran menjadi baik (Roijakkers, 1990).

Keheterogenan kelompok dalam pembelajaran GI memiliki pengaruh terhadap pemahaman dan hasil belajar (Slavin, 2005). Siswa yang belajar di kelompok heterogen menguntungkan bagi siswa berkemampuan akademik rendah. Siswa dengan kemampuan akademik rendah dapat saling berdampingan dan banyak belajar dengan yang berkemampuan akademik tinggi. Siswa dari kelompok akademik rendah mampu memahami materi pelajaran karena diajari oleh temannya. Siswa yang berkemampuan akademik tinggi juga akan mengalami peningkatan hasil belajar karena memahami materi secara mendalam pada saat menjadi tutor untuk temannya.

Pada hasil penelitian, setiap butir soal yang digunakan secara keseluruhan mengalami peningkatan pada kemampuan akhir jika dibandingkan dengan kemampuan awal setiap siswa. Hasil penelitian ini menunjukkan bahwa siswa menguasai materi pelajaran lebih banyak. Hal ini juga memberikan kesempatan bagi siswa yang berkemampuan rendah untuk meningkatkan kemampuan dalam belajar dari siswa yang berkemampuan tinggi. 
Ketiga, pembelajaran GI memungkinkan siswa melakukan penyelidikan. Model GI membuat siswa menjadi aktif dalam pembelajaran mulai perencanaan hingga mencari solusi permasalahan melalui penyelidikan (Kagan \& Kagan, 2009). Keterlibatan siswa secara aktif dalam pembelajaran dapat meningkatkan pemahaman siswa terhadap materi. Hal tersebut terjadi karena dalam GI siswa dihadapkan dengan permasalahan permasalahan perekonomian pada negara-negara berkembang di Benua Asia, termasuk yang terjadi di Indonesia.

Penyelidikan dilakukan siswa dengan mencari informasi dari buku, internet, serta media massa. Siswa melakukan penyelidikan terhadap masalah perekonomian di Benua Asia, sehingga membantu meningkatkan pemahaman siswa terhadap masalah perekonomian. Siswa yang belajar dari penyelidikan dapat mengembangkan pemahaman dan kemampuan akademis (Arends, 2004).

Kegiatan penyelidikan membuat siswa mendapatkan banyak informasi mengenai masalah perekonomian di Benua Asia dan pemahaman yang lebih baik terhadap materi. Penyelidikan merupakan kegiatan pembelajaran yang mengembangkan pemahaman siswa melalui berbagai kegiatan dan hasil belajar siswa (Sumarmi, 2012). Kegiatan penyelidikan mendorong siswa menemukan banyak informasi baru, mengembangkan pemahaman terhadap materi, dan berpengaruh pada peningkatan hasil belajar.

Keempat, pembelajaran dengan model GI dapat mengembangkan keterampilan berpikir tingkat tinggi. Dalam penelitian ini terdapat satu soal esai yang mengukur ranah kognitif tingkat tinggi pada soal nomor lima. Berdasarkan hasil analisis data pada soal nomor lima terdapat perbedaan skor hasil belajar antara kelas ekperimen dan kontrol. Hasil perhitungan skor menunjukkan bahwa rata-rata peningkatan skor kelas eksperimen sebesar 23,80, sedangkan kelas kontrol sebesar 13,15. Perbandingan ini menunjukkan bahwa kelas ekperimen lebih mampu menyelesaikan soal esai ranah kognitif tingkat tinggi dibandingkan kelas kontrol. Perbandingan ini diduga kuat karena penerapan model pembelajaran GI membantu siswa untuk mengembangkan kemampuan kognitif.

Pembelajaran model GI melatih siswa untuk berpikir dalam merancang dan melaksanakan penyelidikan suatu masalah. Model GI melibatkan kemampuan berpikir tinggi dalam menyelesaikan permasalahan, seperti mengidentifikasi informasi, menerapkan pengetahuan untuk merumuskan jawaban, dan mengevaluasi kinerja dalam penyelidikan. Model GI sangat baik diterapkan untuk melatih siswa mengumpulkan informasi untuk memecahkan masalah serta melatih kecakapan berpikir tingkat tinggi siswa (Arnyana, 2004). Jadi dapat disimpulkan bahwa model pembelajaran GI berpengaruh secara langsung dalam meningkatkan kemampuan kognitif siswa terutama kemampuan memecahkan masalah dan kecakapan berpikir tingkat tinggi.

Kelemahan model pembelajaran GI dalam penelitian ini yaitu model ini membutuhkan waktu yang lama terutama pada sintak I yaitu, pengorganisasian siswa ke dalam kelompok penelitian. Pelaksanaan sintak I peneliti membagi siswa ke dalam kelompok berjumlah 2-5 orang dengan mempertimbangkan banyak hal. Kelompok yang dibentuk harus heterogen dari segi jenis kelamin, memiliki minat, dan persamaan dalam masalah penelitian dan mempertimbangkan tingkat keakraban antar teman agar komunikasi dalam kelompok dapat berjalan efektif. Hal ini menjadikan pengorganisasian siswa dalam kelompok membutuhkan waktu lama dalam pelaksanaan model pembelajaran GI. 


\section{Gaya Belajar Berpengaruh terhadap Hasil Belajar Geografi}

Gaya belajar merupakan kecenderungan cara belajar yang disukai siswa sehingga membuat mereka lebih nyaman dalam belajar. Kenyamanan dalam belajar tersebut membuat siswa lebih mudah menerima informasi pelajaran, sehingga berpengaruh terhadap hasil belajar yang tinggi. Siswa dengan gaya belajar visual akan lebih mudah mendapatkan informasi melalui membaca tanpa bersuara. Siswa dengan gaya belajar auditori lebih mudah mendapatkan informasi melalui membaca dengan suara keras dan mendengarkan penjelasan guru. Siswa dengan gaya belajar kinestetik lebih mudah mendapatkan informasi melalui membaca diikuti dengan menggerakkan anggota badan.

Tahapan-tahapan model GI dapat memfasilitasi siswa dengan gaya belajar visual, auditori, dan kinestetik. Tahapan perencanaan penyelidikan dalam kelompok lebih menfasilitasi siswa dengan gaya belajar visual karena pada tahap ini siswa diberikan waktu untuk memikirkan jawaban dari permasalahan yang diberikan, sehingga menumbuhkan sikap mandiri dan siswa lebih berperan aktif dalam proses pembelajaran berlangsung. Siswa dalam tahap ini lebih banyak membaca dalam memikirkan jawaban dari pertanyaan tentang permasalahan yang diberikan. Hal ini sesuai dengan ciri-ciri gaya belajar visual, yaitu: 1) lebih mudah mengingat materi pelajaran dengan melihat gambar; 2) lebih suka membaca; dan 3) suka saat mendapat petunjuk untuk melakukan sesuatu (De Porter \& Hernacki, 2015).

Tahapan melaksanakan investigasi lebih memfasilitasi siswa dengan gaya belajar auditori karena pada tahap ini menimbulkan banyak pembicaraan saat kegiatan diskusi. Siswa pada tahap ini diminta kerja kelompok untuk mendiskusikan jawaban permasalahan yang telah dipilih. Kegiatan ini disukai oleh siswa dengan gaya belajar auditori karena sesuai dengan ciri-ciri gaya belajar auditori, yaitu 1) mudah ingat apa yang didengarnya dan didiskusikannya; 2) lebih suka menuliskan kembali materi yang disampaikan guru; dan 3) bisa mengulangi apa yang didengarnya dari penjelasan guru dan senang diskusi dalam kelas (De Porter \& Hernacki, 2015).

Tahapan menyiapkan dan menyajikan laporan serta evaluasi lebih menfasilitasi siswa dengan gaya belajar kinestetik karena pada tahap ini terjadi gerakan dan kontak tubuh. Siswa dapat mengekspresikan gerakan-gerakan pada saat memberikan tanggapan, saran, dan kritik, sehingga membuat mereka percaya diri dalam proses belajar. Hal ini sesuai dengan ciri-ciri gaya belajar kinestetik, yaitu 1) gemar menyentuh sesuatu yang dijumpainya, misal media alat peraga; 2) banyak gerak fisik dan memiliki koordinasi tubuh yang baik; 3) menyukai kegiatan yang menyibukkan secara fisik, misal kegiatan outdoor learning; dan 4) lebih mendemonstrasikan materi dari pada menjelaskannya (De Porter \& Hernacki, 2015).

Terdapat perbedaan rata-rata hasil belajar geografi siswa yang memiliki gaya belajar visual, auditori dan kinestetik yang dilakukan dengan pembelajaran GI. Siswa yang memiliki gaya belajar kinestetik memperoleh hasil belajar lebih baik dari pada siswa dengan gaya belajar visual dan auditori. Namun tidak menghambat belajar siswa dengan gaya belajar visual dan auditori. Kesimpulannya, pembelajaran GI lebih banyak disukai oleh siswa dengan gaya belajar kinestetik, karena memperoleh hasil belajar yang lebih tinggi dari pada siswa dengan gaya belajar visual dan auditori dalam memahami materi permasalahan perekonomian di Benua Asia.

Siswa yang memiliki gaya belajar kinestetik pada pembelajaran GI ini, juga banyak terlibat dalam kegiatan diskusi. Tahapan menyiapkan dan menyajikan laporan serta evaluasi membuat siswa melakukan aktivitas diskusi yang padat. Hal ini memicu siswa lebih banyak bekerja mencari materi pelajaran untuk menemukan solusi 
pemecahan masalah.

\section{Interaksi Model GI dengan Gaya Belajar terhadap Hasil Belajar Geografi}

Hasil penelitian menunjukkan bahwa tidak ada interaksi antara model pembelajaran GI dengan gaya belajar terhadap hasil belajar geografi. Artinya, gaya belajar tidak memiliki pengaruh berbeda terhadap model pembelajaran GI. Selain itu, model pembelajaran dan gaya belajar bekerja secara sendiri-sendiri terhadap hasil belajar. Pada kelompok eksperimen, rata-rata hasil belajar mahasiswa dengan gaya belajar kinestetik lebih tinggi dari pada visual dan auditori. Pada kelompok kontrol, rata-rata hasil belajar mahasiswa dengan gaya belajar visual lebih tinggi dari pada auditori dan kinestetik. Berdasarkan hasil uji anova dua jalur, didapatkan nilai sig. $(0,102)>0,05$, sehingga tidak ada interaksi antara model GI dan gaya belajar berpengaruh terhadap hasil belajar.

Hal tersebut membuktikan bahwa (1) pengaruh model GI terhadap hasil belajar tidak dipengaruhi oleh gaya belajar, keunggulan model pembelajaran merupakan suatu usaha yang melibatkan siswa dalam memecahkan permasalahan geografi dan (2) siswa pada kelompok eksperimen, baik yang memiliki gaya belajar visual, auditori, maupun kinestetik mendapatkan hasil belajar geografi lebih tinggi apabila belajar dengan pembelajaran model $G I$ daripada kelompok yang belajar dengan model ceramah dan diskusi.

Tidak adanya interaksi antara model pembelajaran GI dengan gaya belajar terhadap hasil belajar diduga karena beberapa hal pertama, model pembelajaran $G I$ tidak bergantung pada gaya belajar siswa. Kedua, model pembelajaran GI lebih memfasilitasi siswa dengan gaya belajar kinestetik dibandingkan dengan visual dan auditori. Ketiga, adanya karakteristik lain pada diri mahasiswa yang belum terkontrol selain gaya belajar.

\section{KESIMPULAN}

Kesimpulan dalam penelitian ini adalah pertama, model Group Investigation berpengaruh terhadap hasil belajar geografi mahasiswa PIPS UIN Maulana Malik Ibrahim Malang. Pengaruh model GI terhadap hasil belajar dalam penelitian ini disebabkan oleh 1) model GI dalam pembelajaran ini menekankan pada perencanaan kelompok; 2) siswa dapat bekerja sama dalam kelompok kecil yang heterogen; 3) pembelajaran GI memungkinkan siswa melakukan penyelidikan; dan 4) pembelajaran dengan model GI dapat mengembangkan keterampilan berpikir tingkat tinggi.

Kedua, gaya belajar berpengaruh terhadap hasil belajar geografi mahasiswa PIPS UIN Maulana Malik Ibrahim Malang. Alasan gaya belajar berpengaruh terhadap hasil belajar geografi, yaitu 1) pada dasarnya setiap siswa mempunyai cara yang berbeda dalam belajar dan 2) tahapan-tahapan model GI dapat memfasilitasi siswa dengan gaya belajar visual, auditori, dan kinestetik.

Ketiga, model GI dan gaya belajar tidak berinteraksi secara signifikan berpengaruh terhadap hasil belajar geografi mahasiswa PIPS UIN Maulana Malik Ibrahim Malang. Hal ini menunjukkan bahwa gaya belajar tidak memiliki pengaruh berbeda terhadap model pembelajaran GI. Selain itu, model pembelajaran dan gaya belajar bekerja secara sendiri-sendiri terhadap hasil belajar geografi. 


\section{UCAPAN TERIMA KASIH}

Penulis berterima kasih kepada semua yang telah membantu dalam penelitian ini. Khususnya mahasiswa Pendidikan IPS, Fakultas Ilmu Tarbiyah dan Keguruan, UIN Maulana Malik Ibrahim Malang.

\section{DAFTAR PUSTAKA}

Arends, R. (2004). Learning to Teach. McGraw-Hill.

Arnyana. (2004). Pengembangan Perangkat Model Belajar Berdasarkan Masalah Dipandu Strategi Kooperatif Serta Pengaruh Implementasi Terhadap Kemampuan Berpikir Kritis Dan Hasil Belajar Siswa Sekolah Menengah Atas Pada Pelajaran Ekosistem. Universitas Negeri Malang.

De Porter, B., \& Hernacki, M. (2015). Quantum Learning. PT Mizan Publika.

Dewi, R. P., Iswari, R. S., \& Susanti, R. (2012). Penerapan Model Group Investigation Terhadap Hasil Belajar Materi Bahan Kimia di SMP. Unnes Science Education Journal, 1(2). https://doi.org/10.15294/usej.v1i2.866

Fajarianingtyas, D. A. (2012). Pengaruh Pembelajaran Berbasis Masalah Melalui Investigasi Kelompok Berbantuan Media 6M Pengelolaan Sampah Terhadap Hasil Belajar Kognitif, Afektif, dan Keterampilan Kerja Ilmiah Mahasiswa IPA Universitas Wiraraja Sumenep Madura. (Tesis). DISERTASI dan TESIS Program Pascasarjana UM, O(0). Retrieved from http://karyailmiah.um.ac.id/index.php/disertasi/article/view/22569

Hasan, S., Rakhman, M., \& Ardiana, H. (2017). Model Cooperative Learning Tipe Group Investigation Untuk Meningkatkan Hasil Belajar Pada Mata Pelajaran Perawatan dan Perbaikan Sistem Refrigerasi. Innovation of Vocational Technology Education, 7(2). https://doi.org/10.17509/invotec.v7i2.6293

Joyce, B. R., Weil, M., \& Calhoun, E. (2008). Models of Teaching. Pearson/Allyn and Bacon Publishers.

Kagan, S., \& Kagan, M. (2009). Cooperative Learning. CalleAmanecer San Clemente: Kagan Publishing.

Ketut, W. N. (2010). Pengaruh Model Pembelajaran Kooperatif Tipe Group Investigation (Gi) Terhadap Hasil Belajar Kimia Dengan Mempertimbangkan Kreativitas Siswa (Studi Eksperimen Terhadap Para Siswa SMA Dwijendra Denpasar). Jurnal Ilmiah Pendidikan dan Pembelajaran Ganesha, 7(1). Retrieved from https://www.neliti.com/id/publications/97828/pengaruh-modelpembelajaran-kooperatif-tipe-group-investigation-gi-terhadap-hasi

Kurniajanti. (2012). Model Pembelajaran Kooperatif Tipe Group Investigation (GI). Retrieved May 17, 2019, from kurniajanti website: https://kurniajanti.wordpress.com/2012/12/30/model-pembelajaran-kooperatiftipe-group-investigation-gi/

Raharjo, S. B. (2010). Pendidikan Karakter Sebagai Upaya Menciptakan Akhlak Mulia. Jurnal Pendidikan dan Kebudayaan, 16(3), 229-238. https://doi.org/10.24832/jpnk.v16i3.456

Richardo, R. (2015). Eksperimentasi Model Pembelajaran Kooperatif Tipe Investigasi Kelompok (Group Investigation) Terhadap Hasil Belajar Matematika Berdasarkan Gaya Belajar Siswa. Edu Research, 4(1), 35-42.

Roestiyah. (2008). Strategi Belajar Mengajar. Jakarta: PT Rineka Cipta.

Roijakkers. (1990). Mengajar Dengan Sukses. Jakarta: PT Gramedia. 
Sharan, S., \& Sharan, Y. (1989). Group Investigation Expand Cooperative Learning. Retrieved from http://www.ascd.org/ASCD/pdf/journals/ed_lead/el_198912_sharan.pdf

Slavin, R. E. (2005). Cooperative Learning. London: Allyn and Bacon Publisher.

Sumaatmadja, N. (1996). Pengantar Studi Sosial. Bandung: Alumni.

Sumarmi. (2012). Model-Model Pembelajaran Geografi. Aditya Media.

Windiatmoko, V. I. (2012). Pengaruh Model Pembelajaran Kooperatif Tipe Group Investigation (GI) Terhadap Hasil Belajar Biologi Ditinjau Dari Gaya Belajar Siswa SMA Negeri 5 Surakarta. Universitas Sebelas Maret.

Zingaro, D. (2008). Group Investigation: Theory and Practice - PDF. Retrieved May 17, 2019, from https://docplayer.net/20922967-Group-investigation-theory-andpractice.html 